\title{
BoNilsson
}

\section{Moralisk exkludering \\ - om tiggare i medier i Norr- och Västerbotten}

\begin{abstract}
Morality and exclusion - media representations of beggars in the north of Sweden
Many public poor from Romania and Bulgaria arrived in the northern parts of Sweden in 2013 and especially in 2014, and a majority of them supported themselves by begging. The media described this new phenomenon in various ways, for example by reporting on how people (Swedes) were outraged because of all the beggars in public spaces. Others, however, described it as if the north of Sweden (finally) had become a part of the rest of the world. This paper discusses how newspapers in Norrbotten and Västerbotten (two large provinces in the north of Sweden) reported on beggars in 2013 and 2014. The overall aim is to qualitatively describe and analyse how the media reported on the beggars, and to discuss the media representations in terms of social inclusion and social exclusion as well as the meanings of morality. This means that the paper examines how journalists and other writers position beggars in relation to a majority population. The aim is also to investigate how journalists and other writers position themselves as moral subjects when they report on this vulnerable group of people. The study identifies four overarching discourses of beggars, and all of these are characterized by social exclusion of beggars even though the writers show inclusive ambitions on moral grounds. One reason for this is found in a subject-object logic that represents an organizing meaning-making principle in all discourses and that results in a categorization of people into "us" versus "them", with the beggars representing the latter.
\end{abstract}

\section{Inledning}

Fattar inte att NÅGON är så djävla dum att de ger slaskpatrasket en enda krona, dom är UTPLANTERADE av sina uppdragsgivare från hemlandet, till tiggeri stölder och annat djävulskap, otroligt att så många svenskar är så dumma att de ger dom pengar.

(http://www.exponerat.net (140915))

I södra Sverige och stora delar av övriga Europa har tiggeri varit en relativt vanlig syn, och har också mötts av misstänksamhet på många håll. Exemplet ovan är bara ett av många där personer som tigger förknippas med kriminella ligor och där man förordar ett förbud mot tiggeri. I norra Sverige har däremot tiggeri varit ett förhållandevis ovanligt inslag i gatubilden. Detta förändrades dock vårvintern 2014 då ett växande antal utsatta EU- 
medborgare sökte sig till Norr- och Västerbotten. Majoriteten av dem var romer från länder som Rumänien och Bulgarien och flera försörjde sig genom att be om pengar och/ eller andra förnödenheter. I de lokala medierna uppmärksammades detta nya fenomen på olika sätt, bland annat rapporterades om människor som var upprörda över att det tiggdes på offentliga platser. Andra såg det som om världen nu ofrånkomligen hade kommit till norra Sverige.

I den här artikeln ska jag diskutera hur dags- och veckopress i Norr- och Västerbotten rapporterade om det ökade tiggeriet under 2013-2014. Syftet är att kvalitativt kartlägga vad och hur medierna rapporterade om människor benämnda som "tiggare" och att diskutera medierapporteringen i termer av inkludering och exkludering. Detta innebär att jag är intresserad av hur journalister och övriga skribenter positionerar tiggare i relation till någon form av majoritetsbefolkning. Vidare är jag intresserad av hur journalister och övriga skribenter positionerar sig själva som moraliska subjekt när de berättar om denna utsatta grupp av människor.

\section{Tidigare forskning}

Det finns en omfattande forskning om socialt utsatta människor, men det är inte alltid lätt att peka på forskning som specifikt behandlar människor som tigger. Många gånger behandlas de tillsammans med andra offentligt fattiga grupper där de inte sällan klumpas samman som "marginaliserade". Så sker ofta i historiska studier där "beggars" beskrivs tillsammans med "travellers", "gypsies", "immigrants", "landstrykare" och "luffare" (se t.ex. Blom 1992; Trolle Önnerfors \& Reslow 2001). Det sker också i studier av hur myndigheter begränsar marginaliserade grupper (Blomley 2010; James 2006) och utövar andra former av makt, t.ex. genom olika former av repressiva praktiker såsom "repressive inclusion", ett slags tvingande rehabilitering (Bochove \& Burgers 2010). En del studier har argumenterat för att kunskapen om tiggeri utgör en biprodukt av forskning om hemlöshet, vilket kan innebära problem med att analytiskt hålla isär olika kategorier (Kennedy \& Fitzpatrick 2001). Att förståelsen av vad som utgör "tiggeri" dessutom varierar mellan olika kulturer komplicerar saken ytterligare (Munoz \& Potter 2014).

Inom den etnologiska ämnestraditionen finns ett etablerat intresse för kategorier som på olika sätt uteslutits ur gemenskaper: "tattare" (Svensson 1993), "rackare" (Egardt 1962), ogifta mödrar (Frykman 1977) och bygdeoriginal (Åkesson 1991) för att ge några exempel. I sin avhandling om "tattarnas spel med rättvisan" påpekar Svensson att vad gäller tiggare så har dessa historiskt sett inte definierats som en särskild kategori, utan tiggeri har snarare utgjort en försörjningspraktik som många fattiga tvingades ta till.

Det finns dock en hel del studier som är inriktade på just tiggare. I tidiga studier använde man sig av typologier och kategoriserade olika typer av tiggare, såsom "store beggars" (Gilmore 1940) och "professional beggars" (Wallace 1965). Undersökningar är också gjorda av tiggares historiska funktion i samhället (Levander 1974; Johanson 1984). Återkommande 
teman i senare tids studier är hur tiggare inkluderas respektive exkluderas i relation till en majoritetsbefolkning. Här kan nämnas Wardhaughs (2009) undersökning av tiggeri i Delhi och Kathmandu, och hur det där är reglerat av både inkluderande och exkluderande tekniker. Ett annat exempel är Swansons (2007) undersökning i Quito av hur olika yrkesgruppers "tal om" tiggare - som 'lazy Indians' som 'prefer to sit and beg' (s 716) - används för att legitimera exkluderande åtgärder. Tiggares strategier för att övervinna osynliggörande berörs i Lankenaus (1999) studie av hur tiggare använder sig av olika teatraliska tiggarrepertoarer för att få omgivningens uppmärksamhet. Ett socialpolitiskt perspektiv framkommer hos Kennedy och Fitzpatrick (2001), vilka förespråkar ett "holistic, interagency approach" (s. 2015) för att kunna bemöta och övervinna de svårigheter som utsatta människor (tiggare) står inför genom att de blir socialt exkluderade (se även Dean \& Keir 1999). Ett "politiskt" anslag finns också hos Lee och Farrell (2003) som har argumenterat emot föreställningar om att tiggare utgör störande inslag i urbana miljöer.

Moralfrågor är också ett återkommande tema. McIntosh och Erskine (1999) menar i en intervjuundersökning att kontakten mellan tiggare och andra människor leder till en moralisk ambivalens som innebär att potentiella givare kategoriserar dem som tigger som antingen genuina eller falska. Också Radford (2001) berör moralfrågor. Han reflekterar över vilka eventuella moraliska principer som kan guida människor när de ställs inför frågan "When should we give to beggars?". En slutsats är att sådana principer inte kan finnas, eftersom frågan är för komplex för att kunna lösas med hjälp av enkla moraliska principer.

Intressant för denna studie är också forskning som problematiserar hur offentligt fattiga representeras i medier. Mediebilder med fokus på hemlösa har bland annat behandlats av Shynne Remillard (2012) och Schneider, Chamberlain \& Hodgetts (2010). De senare poängterar mediernas betydelse för medborgarskap och inkludering, eftersom det är svårt för dessa grupper att själva göra sina röster hörda offentligt. Ett specifikt forskningsfält rör romernas situation och hur romer framställs i medier. Exempelvis har Strausz (2014) påvisat hur rasifierande stereotyper om romer reproduceras i film. Rowe och Goodman (2014) har studerat representationer på diskussionsforum och konstaterar att de ofta förknippas med tiggeri. Författarna identifierade också olika strategier genom vilka "Gypsies are othered, dehumanised, abnormalised, presented as criminal, and not necessarily 'true' Gypises" (Rowe \& Goodman 2014:37). Andra mediestudier visar liknande resultat genom att romer framställs stereotypiserande i termer av tiggare och tjuvar (se t.ex. Clark \& Cambell 2010).

En studie som ligger nära den här är Warius (2011) jämförelse av hur romer representeras i två tidningar, Aftenposten (Norge) och Helsingin Sanomat (Finland). Författaren identifierade två övergripande inställningar till romer, en inkluderande och en exkluderande. Medan den förstnämnda talade för solidaritet och humana värden förknippade den senare romer med bland annat kriminalitet och hot mot den sociala ordningen.

Det finns således en hel del studier som behandlar människor som tigger (och andra 
offentligt fattiga) i termer av inkludering och exkludering. Vad denna studie tillför detta fält är - förutom en kartläggning av här utvalda tidningars innehåll - ett fokus på hur journalister och övriga skribenter förhåller sig moraliskt till människor de benämner som tiggare. Hur hanterar skribenterna den moraliska ambivalens som mötet med tiggare sägs kunna innebära? Vilka (moraliska) subjekt skapas genom mediala framställningar av tiggare och vad betyder dessa för tiggare i termer av inkludering och exkludering?

Ett motiv till att studera medier i norra Sverige är att tiggare var ett nytt fenomen i denna region under den tidsperiod som här avses. Att överhuvudtaget lägga fokus vid pressens representationer av tiggare kan motiveras med att medier utgör en generell informationskälla av avgörande betydelse för hur människor förstår och tolkar företeelser och fenomen i sin omvärld (Hall 1997).

\section{Material och metod}

Materialet baseras på en sökning i mediedatabasen www.retriever-info.com/sv/ med hjälp av sökordet "tiggare"l och ett urval av tidningar/tidskrifter (14 stycken) lokaliserade till Norr- och Västerbotten. ${ }^{2}$ Flera av tidningarna har en relativt bred läsekrets (Norrländska Socialdemokraten har cirka 100000 dagliga läsare och Västerbottens-Kuriren 130 000), de ges ut på regelbunden basis och de innehåller aktuella nyheter. Några är veckobaserade gratistidningar, medan andra är traditionella morgontidningar som finansieras av läsare och annonsörer.

Tidsperioden 130901 - 140901 har jag valt mot bakgrund av att antalet artiklar ökade markant under den perioden och totalt fick jag 184 träffar. Det kan jämföras med 2005 (9 träffar), 2010 (16 träffar) och 2012 (15 träffar). Att jag valde att börja 130901 beror på att jag inte ville missa tidiga artiklar om tiggarna (många anlände som sagt vårvintern 2014) och periodens slut 140901 motiveras med att antalet artiklar minskade tillfälligt i samband med att riksdagsvalet närmade sig. Antalet träffar under tidig höst 2013 låg på bara ett fåtal per månad, men en viss sökning kom successivt och i november nåddes 10 träffar. Tydligaste ökningen kom dock i april och maj 2014 med ett 40-tal träffar per månad. Därefter sjönk antalet träffar under sommaren och landade på 2 i september 2014.

Texterna varierar i karaktär och omfattning, och de representerar olika genrer. Det handlar till exempel om nyheter, längre utredande reportage, krönikor, pressklipp från andra tid-

1 Eftersom en viktig del av syftet med den här artikeln var att undersöka hur norrländsk press representerar människor som de benämner som tiggare valde jag det som sökord. Inte all medierapportering använder sig dock av denna benämning. Exempelvis gav en sökning på "tigg " ANDNOT tiggare" 208 träffar. I dessa användes ibland ord som "EU-migranter", "romer" eller de porträtterade personernas namn (I 16 träffar skrevs om "EU-migranter som tigger" men utan att använda benämningen tiggare. I 26 träffar användes på samma sätt ordet "romer".). En stor andel av dessa artiklar rapporterade om fenomenet på ett mer generellt sätt, utan att överhuvudtaget benämna de personer det var fråga om.

2 Extra Luleå, Extra Malmfälten, Folkbladet, Företag Norrbottningen, Företag och tillväxt i Västerbotten, Nordsverige, Norran, Norrbottens Affärer, Norrbottens-Kuriren, Norrländska Socialdemokraten, Umeå Tidning, Västerbottens Mellanbygd, Västerbottens-Kuriren och Västerbottningen. 
ningar och TT-artiklar. Artiklarna kan handla specifikt om romska tiggare i Norrland, men också om tiggare mer generellt. Det förekommer också artiklar där tiggare bara presenteras som en marginaliserad grupp bland andra. Att jag har beaktat olika typer av artiklar motiveras med att de är publicerade i de norrländska tidningarna och att de sammantaget ger en mångfacetterad bild av tiggeri. Att flera exempel hämtas från Västerbottens-Kuriren beror på att det är en av de tidningar som mest frekvent behandlat tiggare.

Materialet har genomgått en kvalitativ innehållsanalys, vilket betyder att jag inte eftersträvar representativitet i "objektiv" mening, utan att jag vill visa på återkommande föreställningar om tiggare och vilka konsekvenser dessa föreställningar har i termer av inkludering och exkludering. Detta innebär att jag inte har intresserat mig för vilka skribenterna är, utan fokus ligger på vilka föreställningar som är möjliga att uttrycka i anslutning till tiggare.

\section{Teoretiska ansatser}

Den teoretiska utgångspunkten är diskursteori som den är formulerad av Laclau och Mouffe (1985). Med "diskurs" avses specifika sätt att förstå och representera världen eller de resurser människor använder sig av för att begripliggöra företeelser och fenomen. Centralt för diskurser är att de fixerar betydelser på olika sätt och att de ingår i en kamp om "rätten" att definiera vad fenomen ska betyda för människor (Laclau \& Mouffe 1985). I den här artikeln är avsikten att identifiera diskurser i mediematerialet och också att förstå vad de betyder för skribenternas positionering av sig själva och tiggarna.

Ett centralt begrepp är artikulation, vilket jag använder för att förstå hur tecknet "tiggare" länkas samman med olika föreställningar, företeelser och värderingar, och vad som blir effekten av sådana sammanlänkningar. Artikulationer är varken nödvändiga eller slutgiltiga, utan tillfälliga och föränderliga, vilket också utgör diskursteorins yttersta utgångspunkt: mening är kontingent. Exempelvis kan, som redan framgått av litteraturöversikten, tiggeri och tiggare tillskrivas olika betydelser i olika tidsliga och rumsliga kontexter.

Ett närliggande analytiskt begrepp är "flytande tecken". Det syftar på element som är öppna för meningstilldelning och som kan bära på olika betydelser, det vill säga, det kan artikuleras på olika sätt i skilda kontexter. Begreppet "tiggare" har i mediematerialet kvaliteter som gör att det kan förstås som ett flytande tecken genom att det fungerar som en måltavla för skilda attributioner. Medan det i ett visst sammanhang sammanlänkas med ord som gör att det gör anspråk på att beskriva genuint lidande människor, kan det i ett annat tillskrivas innebörder som får tiggare att framstå som fejkande och falska.

En analytisk tanke har varit att identifiera retoriska strategier i materialet. Retoriska strategier syftar på specifika tillvägagångssätt i skribenternas argumentation, såsom individualisering, och på hur sådana strategier strävar efter att fixera betydelsen av flytande tecken. Retoriska strategier handlar också om hur olika diskurser konstrueras och legitimeras. Vilka argument förekommer t.ex. i en diskurs som försvarar tiggare respektive i en diskurs där man framhåller kontroll av tiggares äkthet? Här är jag speciellt intresserad av 
hur journalister och andra skribenter tar stöd av moral och etik, det vill säga av argument som gör anspråk på att förmedla vad som är det rätta handlandet i relation till människor som tigger.

Inkludering och exkludering är två använda begrepp i detta sammanhang. De syftar på hur tiggare positioneras i relation till andra grupper. Med inkludering avses att de görs till ett "självklart" inslag i en majoritetsbefolkning. Exkludering avser det motsatta, att tiggarna inte anses tillhöra majoritetsbefolkningen. Exkludering handlar således om utanförskap (Davidsson 2010) och utestängningsprocesser, dvs. hur tiggare (och andra utsatta grupper) fråntas de sociala, ekonomiska och kulturella band som förbinder dem med ett vidare samfund (Sahlin \& Machado 2008). Begreppet social exkludering är emellertid omdiskuterat, eftersom det kan bidra till att förstärka stigmatiseringen om utanförskapet förstås som ett tillstånd och inte som någonting föränderligt (jfr Koller \& Davidson 2008). Mot bakgrund av detta kommer jag att undersöka både inkluderingar och exkluderingar, och hur detta går till retoriskt i olika diskurser. Materialet kräver också en öppenhet inför vad som blir effekten av olika representationer, eftersom det inte alltid är uppenbart om de fungerar antingen inkluderande eller exkluderande. Därför gör jag också en skillnad mellan betydelseskapande på en manifest och en latent nivå. Analytiskt innebär detta till exempel att argument för att människor som tigger ska bemötas med hänsyn kan förstås som inkluderande på en manifest (explicit) nivå, men exkluderande på en latent (implicit) nivå eftersom de trots allt görs till"de andra".

Konkret har analysen inneburit närläsningar av hur enskilda texter artikulerar tecknet "tiggare". Jag har även undersökt hur skribenterna förhåller sig till de människor som de benämner som tiggare. Görs detta med hjälp av begrepp som tolerans och medmänsklighet eller genom krav på kontroll och autenticitet? Används en likhetslogik eller en skillnadslogik? Vems görs till expert, är det skribenten, intervjuade politiker eller de människor som artiklarna handlar om? Vidare har jag induktivt kartlagt retoriska strategier och återkommande resonemang. Vid jämförelser mellan artiklarna har mönster utkristalliserats som också kan förstås i termer av diskurser. Fyra övergripande diskurser har identifierats, vilka också strukturerar föreliggande artikel: tiggare som samhällssymptom, (icke) autentiska tiggare, lidande tiggare och medkännande skribenter.

Ett ytterligare teoretiskt hänsynstagande utgörs av den reflexiva ansats som innebär att själva forskningsprocessen inte ses som isolerad från det studerade. Utifrån detta perspektiv är en risk med att skriva om utsatta grupper att man själv bidrar till exkludering (jfr Swärd 1999) - även om fokus ligger på medierepresentationer. Att skriva om offentligt fattiga människor som tigger komplicerar saken ytterligare eftersom själva handlingen att be okända om pengar och/eller förnödenheter är stigmatiserad. Denna stigmatisering förstärks genom de ord som oftast används, såväl i medierna som i andra sammanhang. Att använda ordet "tigga" för handlingen, och "tiggare" för dem som utför den, är komplicerat och användandet av ordet "tiggare" har bland annat kritiserats för att vara antiziganistiskt 
(se t.ex. Post m.fl. 2015). "Tiggare" som benämning på en person eller en grupp medför att skälen till handlandet osynliggörs (exempelvis extrem fattigdom) samt att personen reduceras till en enda handling. Tiggeri kan till exempel vara en tillfällig nödstrategi för utsatta människor och inget som de identifierar sig med.

Alternativet till att själv använda uttrycket tiggare skulle kunna vara att skriva exempelvis "offentligt fattiga", "utsatta EU-medborgare" eller "människor som tigger". De första två är problematiska för att de inte benämner det som är den här artikelns fokus, nämligen hur personer som tigger representeras (offentligt fattiga och EU-medborgare säger inget om huruvida personen tigger eller inte). Den tredje liknar den strategi som ofta väljs när personer med funktionsnedsättning benämns, det vill säga att tiggandet, liksom funktionsnedsättningen, konstrueras som något en person gör eller har, inte som något den är. Jag har på grund av ovanstående ibland laborerat med alternativa skrivsätt och begrepp, men eftersom det ökar risken för missförstånd och eftersom tiggare är det begrepp som förekommer i materialet har jag ibland även använt det.

\section{Resultat}

I det följande kommer jag att presentera fyra förhållningssätt till eller diskurser om tiggare. I samtliga diskurser förekommer (direkta eller indirekta) inkluderingar eller exkluderingar, och mer eller mindre uppenbara moraliska överväganden. Det senare behandlas närmare i diskussionen. En diskurs i materialet handlar om att tiggeri beskrivs som ett växande samhällsproblem som antingen EU och ursprungsländerna måste ta ansvar för - inte Sverige - eller som bör förbjudas på grund av att det är störande och förbundet med organiserad brottslighet (jfr Fitzpatrick och Jones 2005). Även om denna diskurs innefattar tydliga exkluderingsprocesser kommer jag inte att ta upp den här, eftersom den främst framkommer indirekt, genom att skribenterna bemöter andras krav på ansvarsöverföring och rättsliga åtgärder. Det är alltså en diskurs som existerar i materialet, men som inte förfäktas av skribenterna.

\section{Tiggare som symptom: en samhällskritisk diskurs}

I vad jag kallat en samhällskritisk diskurs artikuleras tiggare som symptom på omfattande samhällsomvandlingar, lokalt, nationellt och globalt. Dessa samhällsomvandlingar skildras i negativa termer, och skribenterna är kritiska till hur sociala klyftor tillåts öka. Men den samhällskritiska diskursen kan inte bara beskrivas som systemkritisk utan också som inkluderande, eftersom den (indirekt) tar ställning för dem som tigger och för andra offentligt fattiga. Till skillnad från kraven på förbud, där tiggeriet betraktas som själva problemet, läggs alltså här fokus på samhällsutvecklingen och dess negativa konsekvenser.

Detta avspeglas i reportage som förmedlar ett överraskningsmoment; de ger intryck av att människor i Norrland helt plötsligt överrumplades av människor som tiggde under 2014. 
"Jag snubblar snart över alla rumänska tiggare", utbrister en skribent (Västerbottens-Kuriren 140419). Den tid då Sverige och Norrland fungerade som ett slags skyddade zoner från världens orättvisor anses nu vara förbi (jfr Hansson 2014):

Plötsligt kom världen till oss... [...] Vi överrumplades och fylldes alla med obehag. Vad gör de här? Hur hittade de hit? Har de inga hem och har de inga jobb? Och varför tigger de? [...] Vintern 2014 kom världen till Umeå...

(Västerbottens-Kuriren 140512)

För en del tycks erfarenheten av plötsligt uppdykande tiggare ha varit omtumlande. I en artikel beskrivs ett första möte med tiggeri i termer av ett drama som "... utspelar sig framför våra ögon i konflikten mellan välfärdssamhällets trygghet och den synliga fattigdomen ..." (Västerbottens-Kuriren 140517). Här framgår att tiggaren synliggör en form av fattigdom som inte tidigare har kännetecknat Sverige som ett välfärdssamhälle. Enligt skribenterna kan detta förstås nästan handgripligt:

Det har fått som konsekvens att samhällets botten helt plötsligt har kommit och örfilat medborgarna i ansiktet. Det går inte längre att ignorera fattigdomen...

(Folkbladet 140710)

Vidare ger skriverierna intryck av ett samhälle inte bara i förändring, utan i mycket hastig förändring. I flera artiklar blir de som tigger (och andra offentligt fattiga) tecken på ett samhälle som omvandlas i (alltför) hög hastighet och i negativ bemärkelse. Det tycks som om saker och ting är på väg att gå överstyr. Det handlar då inte bara om Norrland, utan generellt om hur det svenska samhället präglas av allt större klassklyftor. I Norran citeras ett pressklipp från Aftonbladet:

\begin{abstract}
När höstkylan drar in över Stockholm ligger hemlösa tiggare på Stureplan. De värmer sig under trasiga filtar medan businessmänniskorna i välputsade skor ilar förbi. Vi är inget jämlikt land längre - om vi nu någonsin varit det.
\end{abstract}

(Norran 130926)

Ord som hemlösa, trasiga filtar och välputsade skor bidrar till kontrastverkan mellan de som har respektive inte har. Dessutom görs de liggande tiggarna till passiva i förhållande till de aktiva businesspersonerna som ilar förbi. Detta skillnadsgörande är centralt i hur tiggarna görs till ett slags symptom på växande och globala orättvisor. Enligt en artikel speglas dessa orättvisor i kontrasten mellan "svensk landsbygd med uttjänta vägar som aldrig kommer att lagas och ett glassigt Östermalm" (Folkbladet 140728), mellan dem som har och dem som är hemlösa och köar utanför systembolaget måndag morgon. 
De samhällskritiska artiklarna speglar således indirekt en svensk folkhemsdiskurs genom att med utgångspunkt i tiggeri som fenomen beskriva vad som har gått förlorat. Om folkhemmet förknippades med välfärd, social jämlikhet, sociala skyddsnät och internationell solidaritet (Jönson 2005), så utgör tiggare beviset på att folkhemmet har ersatts av ett samhälle som präglas av motsatsen, det vill säga bristande sociala skyddsnät och växande klassklyftor. Att människor tigger blir med andra ord ett tecken på att välfärdssamhället inte längre är rustat för att kunna anta den utmaning som de offentligt fattiga utgör (jfr Adler, Bromely \& Rosie 2000). Men tiggarna blir trots allt inkluderade i detta samhälle genom att de ofta fogas samman med andra utsatta grupper. Och på samma sätt som dessa grupper borde tiggarna, enligt diskursen, bemötas med hänsyn och respekt, inte med förakt och fördömanden. Som kommer att framgå av diskussionen kan även denna strävan efter inkludering förstås som en form av exkludering.

\section{(Icke) autentiska tiggare: misstankens diskurs}

McIntosh och Erskine (1999) säger i en undersökning av föreställningar om tiggare i Edinburgh att mötet med tiggande personer är en moraliskt ambivalent erfarenhet. Därför tenderar många människor att kategorisera tiggare som antingen falska eller genuina. Rowes och Goodmans (2014) mediestudie av diskussionsforum visar på liknande resultat genom att romer delas upp i kategorierna "bogus" och "genuine". Denna tendens framkommer också i detta mediematerial, framför allt i artiklar som berättar om hur (enskilda) tiggare beter sig och bör bete sig. En fråga som då återkommer är om de överdriver sin utsatta situation - t.ex. genom att låtsas ha en funktionsnedsättning - eller inte. Här reproduceras en misstankens diskurs, vilken konkret kommer till uttryck genom inslag där man har velat kontrollera om tiggarna är" äkta" eller inte:

Under några timmar observerade VK en tiggande man med käpp, som släpar fötterna
längs backen, darrar kraftigt och har uppenbara problem med att ta sig fram i centrum.
Senare på kvällen ser vi hur han kör bil till en butik några kilometer utanför centrum.
Kryckan är kvar i bilen, han går upprätt in i lokalen och handlar, och det syns inte längre
några tecken på det tidigare så tydliga handikappet.

(Västerbottens-Kuriren 140506)

I samma artikel intervjuas en tiggare som tar avstånd från de som utger sig för att vara funktionsnedsatta: "- Jag skäms verkligen över att det finns vissa personer som gör så här och låtsas vara handikappade. De förstör för oss andra...". De fejkande tiggarna anses således inte bara lura bidragsgivarna, utan också försämra villkoren för andra tiggare.

Men de artiklar som artikulerar tiggare i termer av (potentiella) bedragare ger oftast intryck av ambivalens eller förhandling, dvs. skribenterna reflekterar över vad tiggares livsvillkor kan betyda. Detta innebär att skribenterna inte entydigt bekräftar misstankens dis- 
kurs, utan att de också verkar försvara vissa överdrifter från tiggarnas sida med tanke på deras prekära situation (se t.ex. Norrländska Socialdemokraten 140502):

Nej. Det är inte olagligt att fejka sitt handikapp. Däremot kan det vara orättvist mot andra tiggare, vilket leder till missnöje och bråk om platser.

(Västerbottens-Kuriren 140506)

I samma artikel påpekas också att det bara är ett fåtal av de trettiotal tiggare som finns i Umeå som fejkar sitt handikapp. Skribenten försvarar alltså tiggarna genom att beteckna fejkandet som undantagsfall. Även när det gäller anklagelser om att tiggarna är med i kriminella ligor, att de är rika och kör dyra bilar (Norran 140802) tycks många skribenter stå på tiggarnas sida t.ex. när de påpekar att vad som synes vara onödigt i själva verket måste räknas som rimligt:

\begin{abstract}
... om jag mötte samma tragiska levnadsöde som dessa tiggare och befann mig 300 mil från käresta, barn och vänner skulle nog en mobiltelefon vara det första jag skaffade mig när jag hade råd, om jag inte ägde en sedan tidigare.
\end{abstract}

(Västerbottens-Kuriren 140506)

Vad ovanstående exempel visar är hur föreställningar om den autentiska respektive icke autentiska tiggaren reproduceras i materialet. $\AA$ ena sidan ger materialet uttryck för krav på autenticitet - även om detta är mindre vanligt. För att räknas som en "äkta" tiggare med moralisk rätt att just tigga, behöver personen motsvara ett "riktigt" offer (se även nästa rubrik), dvs. han eller hon ska kunna beskrivas som att oförskyllt ha hamnat i en utsatt situation. Vidare ska denna utsatthet vara offentlig. Inget får döljas eller förvrängas för potentiella givare. Tiggarens iscensättning av äkta nöd (autenticitet) är också, som Munoz och Potter (2013) påpekat, av betydelse för andra människors benägenhet att bidra med en donation. Eventuella (överdrivna) dramatiseringar av offerskap kan frånta personen möjligheten till stöd. I ett reportage ställs t.ex. frågan hur Västerbottens-Kuriren vet att tiggarna talar sanning, och här markeras att tidningen "kontrollerar [...] alla uppgifter så långt det är möjligt" (Västerbottens-Kuriren 140509). Den autentiska tiggaren är också en fråga om antal. När skribenterna "snubblar" över alla tiggare i city (Västerbottens-Kuriren 140419) tycks kraven på autenticitet öka och toleransen minska. Detsamma gäller tiggarnas mobilitet. När de övergår från passivt tiggande i ett gathörn till en mer uppfordrande stil tycks de uppfattas som mer störande och mindre autentiska.

$\AA$ andra sidan förekommer texter som talar emot kravet på autenticitet, vilket som sagt framgår av att vissa skribenter faktiskt försvarar dramatiseringar från tiggarnas sida. Men även i sådana artiklar sker en indirekt reproduktion av idéer om autenticitet och misstankens diskurs, eftersom det trots allt tycks finnas en gräns för vad man får äga och göra som tiggare. Att skribenten i exemplet ovan alls diskuterar föreställ- 


\section{Socialvetenskaplig tidskrift 2015:1}

ningarna om konsumtion och motiverar inköpet av mobiltelefoner genom att hänvisa till sig själv illustrerar att det egentligen inte finns något handlingsutrymme för den som tigger. Oavsett hur autentisk tiggaren verkar vara kan han eller hon misstänkas för att vilja lura "oss" - dvs. "vi" som uppfattas utgöra egentliga medborgare - genom att fejka till sig omgivningens stöd. Med andra ord, även när skribenter förespråkar tolerans med överdrifter reproducerar de misstankens diskurs som bidrar till att göra tiggare till "de andra"; de som trots allt inte är som "vi".

\section{Tiggare som offer: lidandets diskurs}

VK:s team har mött ett ovärdigt liv som inte präglas av människovärde eller värme och omtanke. Tiggarnas liv är inget någon vill uppleva.

(Västerbottens-Kuriren 140426)

Romska tiggare från östra Europa kommer till Sverige för att skaffa pengar till sina familjer. Livet är hårt, blött och kallt och med hemlängtan.

(Norran 131125)

Återkommande i materialet är att skribenter skildrar tiggarnas besvärliga livsvillkor. Ofta görs detta genom referenser till mörker och kyla, smutsiga kläder, trängsel i uttjänta bilar, skam och hemlängtan (Västerbottens-Kuriren 140430). Sådana eländeskildringar har några utmärkande drag. För det första byggs de upp genom individualisering som retorisk strategi. Genom att återge tiggarnas namn och betona deras personliga lidande förstärks framställningarnas känslomässiga karaktär (jfr Andersson \& Valentine 2015). Att de refererade personerna säger sig helt sakna hopp bidrar också till skildringarnas emotionella uppbyggnad. Samtidigt innebär individualiseringen att de skildrade tillåts komma till tals och uttala sig som experter på sin egen situation.

För det andra lyfter skribenterna fram små men symboliskt signifikanta nyckelhändelser i form av motgångar som tiggarna har i sin vardag. Det handlar om ett trasigt dragspel som försvårar försörjningsmöjligheterna (Västerbottens-Kuriren 140426) och om problem med att upprätthålla en rimlig hygienisk standard:

Vi kommer in på hygienen och då berättar Miranda och Sorin att de en gång fått duscha gratis på EFS-kyrkan. Annars kan de duscha på campingen vid Arcus, men eftersom det kostar 50 konor väljer de oftast att inte göra det.

- Och vi har ingen möjlighet att tvätta kläder. Som du känner luktar vi inte så gott.

(Norrländska Socialdemokraten 140520) 
Brist på tvättmöjligheter och dålig lukt är tecken på att tiggarna är utsatta och drabbade, och att de lever ett mer eller mindre miserabelt liv där 50 kronor framstår som en oöverkomlig summa.

Gemensamt för sådana eländesskildringar är att de reproducerar en lidandets diskurs som just handlar om den bedrövelse och de oförtjänta svårigheter som präglar livssituationen. De porträtterade framställs som offer för svåra omständigheter som de själva inte kan råda över. Förutom fattigdom och en vardag i misär drabbas de av fördomar, ziganism och rasism. Offerpositionen förstärks av uppgifter om att situationen i Rumänien är svårare än tidigare. På så sätt görs det också begripligt varför de sökt sig till Sverige och Norrland (Norran 140410). Men i offerberättelserna framkommer också åsikter om att situationen har förvärrats även i Sverige:

Första gången Ioana Marantzelu åkte till Sverige var för fem år sedan. Hemma i byn Malu Vanat i Rumänien gör hon sig redo för en ny tur. Men det har blivit svårare att få ihop pengar. - Nu är det många tiggare och mindre pant. Polisen är inte som tidigare heller. $\mathrm{Nu}$ kontrollerar de oss och kör bort oss, säger hon.

(Norran 140410)

Sammantaget skapar denna lidandets diskurs en sammanhållen bild av umbäranden och svåra livsförhållanden, och hur de som tigger är offer för omständigheter bortom deras egen kontroll. Till viss del motsvarar de "det ideala offret" (Christie 1986) i enlighet med en etablerad viktimiseringsideologi (Best 1999; Nilsson 2003), där offer förstås i termer av personer som utan egen förskyllan och moralisk skuld har drabbats på ett oförsvarligt sätt. En skillnad mot det "ideala offret" är däremot att det vanligtvis saknas en uppenbar gärningsman i tiggerireportagen, men både tiggare och det ideala offret sägs på grund av en svår livssituation vara i behov av omvärldens stöd. Här avspeglas således inkluderande ambitioner, dvs. föreställningar om att tiggare i likhet med andra utsatta grupper och individer bör kunna få samhällets stöd.

Men parallellt med att de som tigger inkluderas i ett"vi", görs de till "de andra" genom att placeras i en kollektiv och passiv offerposition (jfr Warius 2011). Inom ramen för lidandets diskurs tycks de (nästan) helt sakna möjlighet att påverka utformningen av sina liv, eftersom deras tillvaro beskrivs som villkorad av förtryckande strukturer och omgivningens (goda) vilja. Att deras offerskap huvudsakligen beskrivs som ett permanent och inte ett temporärt tillstånd bidrar också till att de trots vissa likheter med "oss" framstår som otvetydigt annorlunda. Trots att offerpositionen tar form i ett retoriskt sammanhang där tiggare inte direkt belastas för sin situation, är den således exkluderande. 


\section{"Människor av kött och blod": medkänslans diskurs}

Mot bakgrund av tiggarnas tillskrivna offerskap hävdas i en del artiklar att det är rimligt att svenskar bidrar med pengar och annan konkret hjälp (Västerbottens-Kuriren 140506; 140514). I sådana artiklar tar skribenterna också avstånd från åsikter om förbud mot tiggeri, förskjutandet av ansvaret till EU och Rumänien eller andra strukturella förhållningssätt. Skribenterna menar förvisso att det behövs strukturella åtgärder för att förbättra situationen på lång sikt, men att i väntan på dessa måste medkänsla och solidaritet sätta sin prägel på individens (svenskars) handlingar i vardagen. Vad skribenterna förespråkar är ett slags vardagsmoralisk hållning enligt vilken människor som tigger ska bemötas med värdighet och respekt:

... jag kommer att ge pengar till tiggare när jag har möjlighet. Det kommer knappast att förändra de strukturer jag anser är skeva i samhället. Men ibland måste man sänka blicken från de stora vyerna och titta på människorna runt omkring sig .

(Folkbladet 140320)

Den här typen av texter kan sägas ligga till grund för en medkänslans diskurs som till skillnad från lidandets diskurs (vilken fokuserade tiggarna) tar fasta på hur "vi andra", inklusive skribenterna själva, ska agera i relation till tiggare. En viktig utgångspunkt är här likheten mellan "oss" och "dem". Många gånger påpekas att tiggare är som "oss", dvs. inte annorlunda, utan människor med samma känslor och rättigheter som alla andra:

Det är viktigt att se den här gruppen människor, inte som identitetslösa tiggare, utan som individer och som människor av kött och blod, med mänskliga rättigheter.

(Norran 140521)

De tiggandes "normalitet" markeras vidare genom berättelser enligt vilka de har samma behov som människor i stort, även om de lever under svåra omständigheter. Uppgifter om fasta tider för uppstigning, arbetsdag och läggdags fungerar som ett slags normalitetsmarkörer (Carlsson 2009) som betonar likhet. Mot bakgrund av denna likhet kan betydelsen av medkänsla motiveras.

Behovet av medkänsla förstärks av uppgifter om att tiggare blir illa behandlade, och att även högt uppsatta politiker sprider rasistiska myter (Västerbottens-Kuriren 140424) och bidrar till främlingsfientlighet (Norran 140430). Med stöd av sådana uppgifter sägs det vara än viktigare med medkänsla i olika former. Förutom gåvor i form av mat, kläder och pengar, är det flera skribenter som återkommer till betydelsen av en blick av erkännande:

... jag uppmanar er att sänka blicken och se era medmänniskor. Även om vi inte vill ha ett välgörenhetssamhälle så är det ändå bättre än ett egoistiskt samhälle.

(Folkbladet 140415) 
De tiggande kan också beskrivas som redskap i skribenternas ansträngningar att stå emot det allt hårdare och skoningslösa samhälle som diskuterades tidigare. Även då tillskrivs blicken betydelse:

Men jag vill alltid se den som sitter där i ögonen och hälsa. Det är ju en människa jag möter. Den ögonkontakten gör något med mig. Kanske kan den bevara mig från hårdhet.

(Västerbottens-Kuriren 140516)

Här framgår att mötet med "den som sitter där" - med dennes blick - kan motverka ett samhälle som förhärdar individer och gör dem okänsliga för andra människors lidanden. Medkänsla beskrivs med andra ord som givande för båda parter. Men för skribenternas del är insikten om (en tidigare eller hotande) personlig okänslighet ingen enkel sak. Skribenterna berättar till exempel att de till en början undvek att ge pengar såväl som att ta ögonkontakt, men att de med tiden har fått tänka om. Utöver personliga möten och ögonkontakt har en viktig katalysator i denna förvandling i något fall varit ett litet barn som utan att tveka har velat dela med sig av sina slantar. Detta har fått skribenten att inse att han eller hon har blivit förhärdad på ett sätt som barnets spontana gest skoningslöst avslöjar (Extra Luleå 140417). Efter detta beskrivs det som omöjligt att undvika dem som tigger, de pockar på uppmärksamhet på ett sätt som en empatisk individ inte kan ignorera. Även om skribenterna själva inte i alla lägen klarar av att agera som de lär, befäster de genom sina ställningstaganden vad de ser som moraliskt riktiga handlingar; vad som är "sann" medkänsla. Men även medkänslans diskurs och påståenden om att tiggarna ska behandlas som medmänniskor kan resultera i exkludering, vilket utvecklas närmare nedan.

\section{Diskussion}

Resultatredovisningen har visat att skriverierna handlade om människor i en utsatt situation. Enligt en samhällskritisk diskurs gjordes dessa människor framför allt till symboler för ett samhälle i förändring, där ett allt hårdare samhällsklimat tvingar fram allt fler offentligt fattiga i dagsljuset.

Inom ramen för lidandets diskurs rättfärdigades tiggeri med hänvisning till lidande, fattigdom och förtryck. Retoriska strategier som individualisering och emotionella anspelningar (jfr Andersson \& Valentine 2015) förstärkte bilden av tiggarna som offer samtidigt som normalitetsmarkörer fick dem att framstå som lika "oss". Men det hände också att tiggarna ställdes till svars för sina handlingar genom misstankar om orättfärdigt tiggeri. Inom ramen för en misstankens diskurs framgick att inte vem som helst kan utge sig för att vara tiggare. Gestalten tiggare ska spegla individens sanna livssituation. Även om en del skribenter - i linje med McIntosh och Erskines (1999) undersökning - gav uttryck för ett ambivalent förhållningssätt och försvarade vissa överdrifter, skapades trots allt gränser 
för vad som är rimligt. En mobiltelefon kunde eventuellt rymmas inom denna rimlighet, men i övrigt tycktes en situation präglad av hårda livsvillkor passa bäst med den autentiska tiggaren, dvs. med den som har moralisk rätt att åberopa andras medkänsla. Skriverierna handlade dock inte enbart om tiggarna, utan direkt eller indirekt också om skribenterna själva. I artiklarna positionerade sig textförfattarna som moraliska subjekt, vilket mest tydligt framkom i medkänslans diskurs. Här förhandlade skribenterna med olika möjliga förhållningssätt till tiggare och oftast utmynnade detta i ett ställningstagande för empati: Tiggare ska behandlas som medmänniskor, inte som ett strukturellt samhällsproblem. Medkänslans diskurs uppvisade således likheter med den inkluderande inställning som Warius (2011) identifierade i sin mediestudie och som byggde på argument om solidaritet och humana värden.

Skribenternas moraliska positionering förtydligades genom ett slags process av självupprättelse. Mötena med tiggande människor beskrevs som moraliskt prövande, vilket medförde att skribenterna inte kunde ignorera de utsattas nöd. Det var också mot bakgrund av sådana situationer som skribenterna förespråkade ett slags situations- eller dygdeetik, där det är människans handlande i varje vardaglig situation som räknas. En god människa är vanemässigt god (Collsté 2010): "Låt oss inte intellektualisera för mycket innan vi gör en god handling, handla gott för sakens skull" (Västerbottens-Kuriren 140426).

Men vad innebär egentligen skribenternas positionering som moraliska subjekt i relation till dem som beskrivs? Å ena sidan finns en strävan att på en manifest nivå inkludera tiggarna i ett "vi". De utesluts i alla fall inte ur "vårt" förpliktelseuniversum och de görs inte fullständigt moraliskt osynliga (vilket Bauman (2000) menade var fallet med judarna i koncentrationslägren). Skribenterna poängterar verkligen att de aktivt och regelbundet söker ögonkontakt med de drabbade (efter processen av självupprättelse) och strävar efter att behandla dem som medmänniskor. Å andra sidan sker på en latent nivå genomgående en exkludering. Denna exkludering kan relateras till att meningsskapandet i här identifierade diskurser är organiserat av en subjekt-objekt-logik som resulterar i att skribenterna görs till subjekt och tiggarna till objekt. Mer precist, subjekt-objekt-logiken leder till en exkludering av tiggarna på fyra skilda men närliggande sätt.

För det första genom att skribenterna vanligtvis skriver om "vi", "oss" och "våra värderingar" och i dessa begrepp ryms inte de som tigger (jfr Lynn \& Lea 2003). De utgör "de andra", tillfälliga besökare som "vi" ska respektera och bemöta på ett moraliskt acceptabelt sätt. Vad som inbegrips i detta "vi" är inte alltid uppenbart, men det tycks handla om "vi svenskar", "vi lulebor" eller "vi umebor" som står i kontrast till "tiggarna". Detta "vi" framställs ofta som relativt enhetligt, men det är också - vilket påpekades tidigare - ett vi som utsätts för prövningar i mötet med de fattiga: 
Jag vill [...] att vi Umeåbor börjar reflektera vad som händer i oss när jag ser en människa sitta på marken, sträcka ut en mugg och be om pengar. Kan jag titta på den här människan, hälsa, möta en på något sätt, eller ignorerar jag den totalt och låtsas som att den inte fanns? Vi som möter dessa människor får en chans att göra upp med våra egna värderingar, det är i praktiken det märks. [...] Vågar vi se dessa människor i ögonen och kväva våra tendenser till undanflykter?

(Västerbottens-Kuriren 140426)

I detta exempel är det ett jag/vi som innehar agens och som kan välja att titta, hälsa på och möta "den andre". Tiggarna tycks själva sakna denna möjlighet, betydelsen av deras vädjanden är villkorade av "vi:et". Detta kan framstå som självklart, men skapandet av ett enhetligt och agerande vi är i sig exkluderande. De andra kan inget annat göra än att vänta på att "vi:et" ska "göra upp med sina värderingar" och bemöda sig med "ett leende, något varmt att dricka, en tanke av vänskap och välvilja" (Västerbottens-Kuriren 140426). Det sker med andra ord en uppdelning i subjekt och objekt, där tiggarnas förväntade objektsposition förstärks av uppgifter om deras (bristande) mobilitet. En stillasittande tiggare tycks vara att föredra, då genuint fattiga inte förväntas att vara aktiva (jfr McIntosh \& Erskine 1999; Hansson 2014). Den potentiella likheten mellan "vi" och "dom" som produceras i materialet är således villkorad, eftersom det skapas ett "vi" som har exklusiv rätt att erkänna ett" dom". Bara att tala om "tiggare som människor" och att de är"som alla andra" är avhumaniserande och ett uttryck för "extreme othering". Det är sällan relevant att tala om andra grupper, t.ex. busschaufförer, i termer av att de faktiskt är människor (Warius 2011).

Exkludering av dem som tigger sker för det andra genom att skribenterna intar en försvarande och skyddande position. De tar ställning för tiggare och andra offentligt fattiga i förhållande till ett allt hårdare samhällsklimat. De försvarar dem också mot anklagelser om internationella tiggarligor och om arbetsskygghet. Detta försvar innebär att författarna indirekt gör anspråk på en hjälteroll (jfr Eide 2002). De vågar stå upp emot orättvisor som drabbar tiggare och de positioneras som tiggarnas språkrör. Men hjälterollen kräver ett offer, någon att hjälpa och försvara. Detta innebär att skribenterna huvudsakligen talar för "den andre", inte tillsammans med "den andre", vilket i sig är en makthandling som innebär ett upprättande av ett "vi" kontra "dom". Med andra ord, försvaret av tiggarna som en inkluderande strategi mynnar samtidigt ut i exkludering.

För det tredje förespråkar skribenterna tolerans med tiggare och deras eventuella fejk. Men tolerans är ett tveeggat svärd eftersom att tolerera någon utgör en handling som inbegriper maktutövning; det är någon (ett subjekt) som ska tolerera någon annan (ett objekt). Den toleranta tillskrivs en priviligierad position, den som är aktiv och har makten att acceptera andra, men indirekt också att exkludera (jfr de los Reyes \& Mulinari 2005). Den som blir tolererad fråntas makt: den har bara förhoppningen om att bli tolererad. Tolerans bidrar således också till en uppdelning i "vi" och "dom", men även till en rangordning av detta "vi" 
och "dom". De förstnämnda framstår som de goda, eftersom de genom sin tolerans skapar (retorisk) plats för ett "dom" utan att själva vinna något på detta. Tolerans reproducerar således skillnad och "vi:et" som (överordnad) normalitet återskapas genom marginalisering av de andra, inte genom direkt uteslutning (jfr Brown 2004:25) eftersom en sådan uteslutning hade uppfattats som moraliskt oacceptabel. Grundläggande för tolerans är således att de andra kvarstår som just de andra och att föreställningar om normalitet vidmakthålls.

För det fjärde förespråkar skribenterna att en gåva i vardagen är rimlig eftersom den trots allt kan förbättra tiggarnas omedelbara situation. Men på samma sätt som tolerans kan gåvor och välgörenhet beskrivas som makthandlingar, eftersom mottagaren hamnar i skuld och ska (helst) känna och uttrycka tacksamhet över vad han eller hon har erhållit. Välgörenhet fungerar på så sätt som ett redskap för social kontroll (jfr Stern 1986) genom att den producerar både skuld och godhet. Detta innebär också produktion av skillnad, där skribenternas moraliska subjekt representerar det goda, medan de som tigger görs till "de andra" som sätts i skuld. Mottagarens oförmåga att "betala tillbaka" annat än symboliskt i tack och leenden befäster dennes underlägsenhet och givarens överlägsenhet (Mauss 1970).

Skribenternas förespråkade vardagsmoral underbyggs av den geografiska dimension som antyddes ovan och som avspeglas i uppgifter om att människor i Norrland är vänligare och mer förlåtande än på många andra platser. Ofta är det tiggarna själva som får vittna om detta, "att människor i norr är mer givmilda och behandlar dem bättre" (VästerbottensKuriren 140509). Den typen av uppgifter rättfärdigar också skribenternas positionering som goda människor trots att de, förutom ett ögonkast och en slant då och då, egentligen ignorerar de moraliska krav och förväntningar som uppstår i mötet med behövande (jfr Brytting 2001). Den trivialisering av vardagens handlingar som detta innebär är en central aspekt av exkluderingens logik. Enligt Brytting (2001) handlar moralisk kompetens om att inte betrakta vardagens handlingar som triviala, utan som betydelsebärande. Men när skribenterna berättar om hur de passerar förbi människor i nöd med hjälp av ett ögonkast, en hälsning eller ett mynt som alibi, sker just en trivialisering, dvs. en trivialisering av vad själva passerandet innebär: Den människa som tigger liksom dess situation förringas samtidigt som skribenten genom sin symboliska uppoffring - en blick, en hälsning eller ett mynt - övervinner en hotande ambivalens och säkrar sin moraliska status som (en god) medmänniska.

\section{Referenser}

Adler, Michael, Bromely, Catherine \& Rosie, Michael (2000) Begging as a challange to the welfare state. I Jowell, Roger et al. (eds), Brittish Social Attitudes. Focusing on Diversity. The 17th Report. London: Sage. Andersson, Johan \& Valentine, Gill (2015) Picturing the poor: fundraising and the depoliticisation of homelessness. Social \& Cultural Geography, 16(1): 58-74.

Bauman, Zygmunt (2000) Modernity and the Holocaust. Ithaca, NY: Cornell University Press.

Best, Joel (1999) Random Violence. How We Talk About New Crimes and New Victims. Berkeley and Los Angeles: University of California Press. 
Blom, Conny (1992) Tiggare, tidstjuvar, lättingar och landstrykare: studier av attityder och värderingar $i$ skrån, stadgar, ordningar och lagförslag gällande den offentliga vården 1533-1664. Bibliotheca historica Lundensis 73.

Blomley, Nicholas (2010) The Right to Pass Freely: Circulation, Begging, and the Bounded Self. Social \& Legal Studies, 19(3): 331-350.

Bochove, Marianne van \& Burgers, Jack (2010) Disciplining the Drifter. British Journal of Criminology, 50(2): 206-221.

Brown, Wendy (2004) Tolerance and/or Equality?: The "Jewish Question" and the "Woman Question". Differences, 15(2):1-31.

Brytting, Tomas (2001) Att vara som Gud? Moralisk kompetens i arbetslivet. Malmö: Liber.

Carlsson, Eric (2009) Medierad övervakning. En studie av övervakningens betydelse i svensk dagspress. Umeå: Umeå universitet.

Christie, Nils (1986) The Ideal Victim. I Fattah, Ezzat A (ed), From Crime Policy to victim Policy. Reorienting the Justice System. London: Macmillan.

Collsté, Göran (2010) Inledning till etiken. Lund: Studentlitteratur.

Clark, Colin \& Cambell, Elaine (2000) 'Gypsie invasion': A critical analysis of newspaper reaction to Czech and Slovak asylum-seekers in Britain 1997. Romani Studies, 10(1): 23-47.

Davidsson, Tobias (2010) Utanförskapelsen. En diskursanalys av hur begreppet utanförskap artikulerades i den svenska riksdagsdebatten 2003-2006. Socialvetenskaplig tidskrift, 2(17):149-169.

Dean, Hartley \& Gale, Keir (1999) Begging and the contradictions of citizenship. I Dean, Hartley (ed.) Begging Questions. Street-level Economic Activity and Social Policy Failure. Bristol: Policy Press.

de los Reyes, Paulina \& Diana Mulinari (2005) Intersektionalitet: kritiska reflektioner över (o)jämlikhetens landskap. Malmö: Liber.

Egardt, Brita (1962) Hästslakt och rackarskam. En etnologisk undersökning om folkliga fördomar. Stockholm: Nordiska museets Handlingar 57.

Eide, Elisabet (2002) "Down there" and "up here". "Europe's Others' in Norwegian feature stories. Oslo: Faculty of Arts Unipub.

Fitzpatrick, Suzanne \& Jones, Abwen (2005) Pursuing Social Justice or Social Chesion? Coercion in Street Homelessnes Policies in England. Journal of Social Policy, 34(3):389-406.

Frykman, Jonas (1977) Horan i bondesamhället. Stockholm: Prisma.

Gilmore, Harlan W. (1940) The Beggar. Chapel Hill: University of North Carolina Press.

Hall, Stuart (1997) Representation: cultural representations and signifying practices. London: Sage.

Hansson, Eric (2014) "Som att världen har kommit hit". Stockholmares upplevelser av tiggeri våren 2014. Kulturgeografiska institutionen. Stockholms universitet.

James, Zoë (2006) Policing Space. Managing New Travellers in England. British Journal of Criminology, 46(3):470-485.

Johanson, Ulla (1984) Fattiga och tiggare i Stockholms stad och län under 1700-talet. Studier kring den offentliga fattigvården under frihetstiden. Stockholm: Liber.

Jönsson, Håkan (2005) Social democratic aging in the People's Home of Sweden, Journal of Aging Studies, 19(3):291-308.

Kennedy, Catherine \& Fitzpatrick, Suzanne (2001) Begging, Rough Sleeping and Social Exclusion: Implications for Social Policy. Urban Studies, 38(11):2015.

Koller, Veronika \& Davidson, Paul (2008) Social exclusion as conceptual and grammatical metaphor: a cross-genre study of British policy making. Discourse \& Society, 19(3): 307-331.

Laclau, Ernesto \& Mouffe, Chantal (1985) Hegemony and socialist strategy: Toward a radical democratic politics. London: Verso. 


\section{Socialvetenskaplig tidskrift 2015:1}

Lankenau, Stephen E. (1999) Panhandling repertoars and routines for overcoming the nonperson treatment, Deviant Behavior, 20(2): 183-206.

Lee, B A and Farrell, C R (2003) Buddy, can you spare a dime? Urban Affairs Review, 38(3): 299-324.

Levander, Lars (2004) Fattigt folk och tiggare. Institutet för folklivsforskning vid Nordiska museet och Stockholms universitet.

Lynn, Nick \& Lea, Susan (200). 'A phantom menace and the new apartheid': The social construction of asylum-seekers in the United Kingdom. Discourse Society, 14(4): 425-52.

Mauss, Marcel (1970) The gift. Forms and functions of exchange in archaic societies. London: Routledge \& Kegan Paul.

McIntosh, Ian \& Erskine, Angus (1999) "'I feel rotten, I do, I feel rotten". Exploring the begging encounter'. I Hartley, Dean (ed.), Begging Questions: Street-level economic activity and social policy failure: Bristol: Policy press.

Munoz, Christian Pérez a\& Potter, Joshua D. (2014) Street-level charity: Beggars, donors, and welfare policies, Journal of Theoretical Politics, 26 (1): 158-174.

Nilsson, Bo (2003) Brottsoffer. Offerskapets innebörder och villkor i (o) säkerhetens kultur. Umeå: Boréa.

Post, Soraya m.fl. (2015) Antiziganistiska myter i svenska medier. Opinon, http://www.svt.se/opinion/article2817301.svt.

Radford, Colin (2001) Begging Principles: The Big Issue, Journal for Applied Philosophy, 18(3): 287.

Rowe, Lottie \& Goodman, Somin (2014) "A stinking filty race of people inbred with criminality". A discourse analysis of prejudicial talk about Gypsies in discussion forums, Romani Studies, 24(1): 25-42.

Sahlin, Ingrid \& Machado, Nora (2008) Diskriminering och exkludering. En introduktion. Socialvetenskaplig Tidskrift, 15(3-4): 174-184.

Schneider, Barbara, Chamberlain, Kerry \& Hodgetts, Darrin (2010) Representation of Homelessness in Four Candian Newspapers: Regulation, Control and Social Order. University of Calgary: Department of Communication and Culture.

Shynne Remillard, Chaseten (2012) Visual Representations of Homelesness in the Candian Public Sphere: An Analysis of Newspapers and Photo Voice Images. University of Calgary.

Stern, M. J. (1986) The emergence of the homeless as a public problem. I Ericson, J \& Wilhelm, C (eds), Housing the Homeless, London: Routledge.

Strausz, Laszlo (2014) Producing prejudice: The rhetoric of discourses in and around current films on Roma Hungarian interethnic relations. Romani Studies, 24(1): 1-24.

Svensson, Birgitta (1993) Bortom all ära och redlighet. Tattarnas spel med rättvisan. Stockholm: Nordiska museets Handlingar 114.

Swanson, Kate (2007) Bad Mothers and Delinquent Children: Unravelling anti-begging rhetoric in the Ecuadorian Andes, Gender, Place \& Culture: A Journal of Feminist Geography, 14(6): 703-720

Swärd, Hans (1999) Att forska om utsatta. Socialvetenskaplig tidskrift, 6(2): 172-183.

Trolle Önnerfors, Elsa \& Reslow, Patrick (2001) Luffare, tiggare, glädjeflickor och nasare. Om lösdrivarelagstiftningen i Sverige från medeltiden till folkhemmet. Från Schlyters lustgård: rättshistoriska uppsatser.

Wallace, Samuel (1965) Skid Row as a Way of Life. Totowa, NJ: Bedminister press.

Wardhaugh, Julia (2009) Regulating social space: Begging in two South Asian cities, Crime Media Culture, 5(3): 333-341.

Warius, Johanna (2011) "And now to the rest of the trash..." Representations of begging Roma and an ideal society in two Nordic newspapers. University of Helsinki.

Åkesson, Lynn (1991) De ovanligas betydelse. Stockholm: Carlsson. 


\section{Internetkällor}

http://www.exponerat.net/de-zigenska-tiggarna-i-umea-snyftar-ut/

\section{Författarpresentation}

Bo Nilsson, Professor i etnologi, Institutionen för kultur- och medievetenskaper vid Umeå universitet;

bo.nilsson@umu.se 